\title{
Health: The main ally for support of the anti-tobacco law in Spain
}

\author{
Lourdes Biedma-Velázquez \\ Elena Espinosa-Monteros \\ Rafael Serrano-del-Rosal \\ Consejo Superior de Investigaciones Científicas (CSIC). \\ Instituto de Estudios Sociales Avanzados (IESA) \\ lbiedma@iesa.csic.es; eespinosa@iesa.csic.es; rserrano@iesa.csic.es
}

\begin{abstract}
Objective: To determine the sociodemographic characteristics and opinions that predict citizens' attitudes towards the anti-tobacco law in Spain.

Methods: Data was analyzed from a telephone survey on smoking habits conducted among citizens of Spain in 2008 by the Centro de Investigaciones Sociológicas (CIS). The sample was stratified by region and size of habitat, establishing age and sex quotas. A descriptive analysis is provided of the main results. A forward stepwise logistic regression analysis was performed with opinions about the anti-tobacco law as a dependent variable and sociodemographic characteristics of the respondents as independent variables.

Results: The perceived effectiveness of the law in terms of health benefits and reduction in number of smokers and cigarettes consumed has the greatest predictive power on support for the anti-tobacco law.

Conclusion: Policies aimed at improving public health must meet with the support of citizens. In order to garner this support it is essential that citizens be informed about the effectiveness and health benefits of restrictive legislation such as anti-tobacco laws.
\end{abstract}

Keywords: Health policies; tobacco control; public opinion; Spain.

Resumen. La salud, el principal aliado de la aceptación de la "ley antitabaco" en España

Objetivo: Analizar qué características sociodemográficas y de opinión predicen el respaldo de los ciudadanos a la Ley antitabaco en España.

Métodos: Se han analizado los datos de una encuesta telefónica realizada en 2008 por el Centro de Investigaciones Sociológicas (CIS) sobre hábitos relacionados con el tabaco a población española, estableciendo cuotas de sexo y edad y con distribución por Comunidades Autónomas y tamaño de hábitat. Se ha realizado un análisis descriptivo de los principales resultados, y un análisis de regresión logística (stepwise forward) siendo la variable dependiente la posición ante la ley antitabaco y como variables independientes las características sociodemográficas del entrevistado, y las opiniones sobre la ley. 
Resultados: Lo que más predice la posición favorable a la ley es la apreciación de su efectividad, es decir, la percepción de que la ley ayuda a mejorar la salud de la población, que ayuda a reducir el número de fumadores y la cantidad de cigarrillos fumados.

Conclusión: Es necesario que la población apoye políticas sanitarias que son claramente beneficiosas para la salud pública en general. En este sentido, la información sobre la efectividad de la ley se postula como un elemento decisivo para conseguir el respaldo popular necesario para llevar a cabo políticas restrictivas y/o prohibitivas.

Palabras clave: políticas de salud; control del tabaco; opinión pública; España.

\author{
Summary \\ 1. Introduction 4. Discussion \\ 2. Material and methods Acknowledgements \\ 3. Results Bibliographic references
}

\title{
1. Introduction
}

"Smoking kills". This slogan has been repeated on numerous occasions from both scientific and public spheres. A vast amount of data is available on the number of direct and indirect deaths attributed to smoking by type of disease, country and region (US-DHHS, 2006; Pierce and Leon, 2008: 614; Murray and López, 1997: 1436; García, 2001: 53), while numerous predictions have been made on mortality, morbidity and the short- mid- and long-term effects of smoking (WHO, 1999; Mackay and Eriksen, 2002). While practically everyone is aware that "smoking kills", the slogan seems to have lost its persuasive power as tobacco consumption has now become a major public health concern in developed countries. According to the World Health Organization (WHO), which defines health as a state of complete physical, mental and social wellbeing (WHO, 1952), tobacco consumption is one of the most serious health threats of our times (Mackay and Eriksen, 2002).

Although citizens today are sufficiently well-informed about the hazards of smoking, at the individual level they have not modified their conduct in terms of physical, psychological or social dependence on tobacco (Betancourt and Navarro, 2001: 85). Indeed, people now smoke more than 50 years ago and the tobacco epidemic is predicted to be even worse in another 50 years (Mackay and Eriksen, 2002). Data from the National Health Survey of Spain (ENSE) indicate that tobacco consumption in the country is declining, although not at the same pace as neighboring countries (Camarelles, 2004: 464). According to Lopez' model of smoking prevalence in developed countries (López et al., 1994: 243), Spain is currently in Stage III of the tobacco epidemic.

Although there exists a "clear" collective discourse on the different relationships between smoking and health problems ("it is bad for your health", "it is bothersome", "children and teenagers should not be exposed to cigarette smoke", etc.), the fact is that smoking has not been rejected by society as a whole in line 
with this discourse. In this regard, media campaigns can be effective in garnering citizen support for tobacco control policies not only through exposure to anti-tobacco advertising, but through public dialogue about the hazards of tobacco and anti-smoking socialization (Blake et al., 2010: 191).

In terms of its legislative efforts, Spain has been slow in embracing the recommendations of the WHO Framework Convention on Tobacco Control (FCTC) to implement a regulatory strategy in response to the tobacco epidemic of the $21^{\text {st }}$ century (WHO, 2000). The anti-tobacco law of Spain, the "Ley Antitabaco" - Law 28/2005 of 26 December (BOE, 2005: 4224142250) - entered into force in late 2005 with the support of all the political parties in parliament. The law provided for restrictions on the sale of tobacco (where tobacco can be sold), tobacco consumption (where tobacco can be consumed) and tobacco advertising (how and where tobacco can be advertised), as well as measures targeted at prevention and health education. Although the law of 2005 marked a radical change with respect to previous anti-smoking legislation —one of the most permissive in Europe (Fernández et al., 2006: 151) - it was by no means a model law. Because the law provided a loophole that permitted smoking in public places that fulfilled certain conditions (ventilation, separate smoking zones, size of locale, etc.), Spain's law of 2005 was largely touted by the tobacco industry as a model for other countries (Muggli et al., 2010: 28) with the argument that it promoted a climate of tolerance between smokers and non-smokers. Unlike Spain, other countries of Europe have readily embraced legislation that complies more strictly with the WHO guidelines by prohibiting smoking in public spaces such as bars and restaurants to protect workers and clientele from the adverse effects of exposure to second-hand smoke (SHS). Although these restrictive laws have proven to be effective and have no significant impact on business (Eadie et al., 2010: 24), the hospitality sector of Spain as well as smokers' associations and certain regional governments such as the Community of Madrid have strongly opposed the implementation of smoke-free legislation.

Later, in the year 2010, the Spanish government adopted the "new antitobacco law" - Law 42/2010 of 30 December (BOE, 2010: 109188-109194) which extended the ban on smoking in all collective spaces, public locales and even some outdoor venues. This new, more restrictive law was passed unanimously again with the consensus of the two major political parties, the Spanish Socialist Workers' Party (PSOE) and the People's Party (PP). However, the political changes introduced by the new law are still subject to multiple statements by prominent politicians of the PP that explicitly or implicitly call into question the new legislation from time to time; statements which have resulted in significant media coverage and intensified the public debate.

In spite of opposition to the law, there is clear evidence that restrictive government policies are one of the most effective ways to reduce the number of smokers and the number of cigarettes consumed. According to Bruntdtland (Mackay and Eriksen, 2002), there is a solution to the tobacco epidemic; a solution routed through political measures following the guidelines set down 
by the WHO. Nonetheless, legislative measures that differ between countries lead to health inequalities among citizens that cannot be justified from either a political or a social standpoint.

The anti-tobacco measures implemented by neighboring countries (chiefly the European Community) have proven to be effective in reducing the number of smokers. In addition to strategies targeted at curbing tobacco use such as pricing policies and advertising bans, citizens have been informed about the risks of smoking for both smokers and those exposed to second-hand smoke. These campaigns have created a favorable climate and led to greater support for policies aimed at restricting the consumption of this legal drug (INSP, 2001). Moreover, support for smoke-free policies has been observed to increase once the policies are introduced and their effects are made visible (Jamrozik, 2004: 760; El País, 2012).

Education in terms of both knowledge and socialization is essential in eradicating this bad health habit, while popular support for anti-smoking legislation that has a direct effect on lifestyles and habits of consumption is key to ensuring that these measures are implemented successfully. It is also important that the positive effects of the law are not delegitimized by pressure groups opposed to the law in order to permanently eradicate this pandemic.

The tobacco industry of Spain has made great effort to convince the public that the consumption of tobacco products forms an intrinsic part of Spanish culture and is closely associated to the character and lifestyle of the Spanish and should therefore be respected (Fernandez et al., 2006: 150). To counteract such tactics and break the circle of tolerance surrounding this product, public bodies must create a climate that is receptive to tobacco restrictions in public places by equating consumption to an addiction that must be prevented and controlled.

Smoking is an addictive habit that cannot be eliminated solely in physical terms by dealing with withdrawal symptoms or addiction to nicotine, but must also take account of subjective factors such as motivation, self-confidence, awareness and socialization.

Given the above, it is of great importance to gain insight into the opinions of citizens regarding anti-smoking legislation. To do so, the objective of this paper is to determine which factors contribute to positive or negative attitudes of citizens towards the anti-tobacco law of 2005, bearing in mind their sociodemographic characteristics, opinions about the effectiveness of the law, smoking habits and health issues. While we are aware that this paper would have been more complete if citizens' opinions could have been analyzed following the entry into force of the new anti-tobacco law, no data are currently available to do so. However, the ambiguity and even the opposition of Popular Party leaders (now in government) on the new smoking ban (El País, 2011a), who even advocate reinstating the above law, reinforces the interest of this work.

\section{Material and methods}

We have analyzed data from a survey conducted in 2008 by the Spanish Center for Sociological Research (CIS) on tobacco-related habits titled "Hábitos 
relacionados con el tabaco" [Tobacco-related Habits]. The survey is available on the CIS website (www.cis.es).

A total of 2002 telephone interviews were conducted of Spanish citizens aged 18 years and over. The sample was distributed into strata by region and size of habitat, establishing age and sex quotas. The telephones/households were selected randomly from the telephone directory for each stratum. One respondent from each household was selected according to quotas of sex and age. A maximum a priori error of $\pm 2.24 \%$ was assumed for a two-sigma confidence level.

In what follows, we present the main descriptive results of the survey, indicating when the differences are statistically significant by means of the Pearson chi-square significance test.

In order to determine which sociodemographic characteristics have an effect on attitudes towards the anti-tobacco law (with two possible variables: "for the law" or "against the law"), we performed a logistic regression analysis. The sociodemographic characteristics of the respondents (age, sex, educational level, vote in the last general elections), the perceived effects of the law, if the respondent smokes or if smoking bothers the respondent have been used as regressor variables. The logistic regression method applies a maximum likelihood estimation after transforming the dependent variable into a logit variable (the natural $\log$ of the odds of the dependent variable occurring or not). In this way, the logistic regression estimates the odds of a certain event occurring. Specifically, the stepwise regression method with forward selection involves starting with no variables in the model, trying out the variables one by one, and including them if they are statistically significant.

\section{Results}

In $2008,28.4 \%$ of males and $21.5 \%$ of females over the age of 18 in Spain were smokers. Tobacco consumption among males has dropped considerably in the last 30 years, while consumption among females has risen in the same period, although it began to fall after 2003. As can be seen in Figure 1, the percentage of smokers of both sexes is now similar. While in 1978 there was a difference of 48 percentage points between male and female smokers, the difference was only 6 points in 2008 .

According to the survey, $55.3 \%$ of smokers do not intend to quit smoking. This figure increases to $56.8 \%$ among smokers who believe that the law does not have a significant effect on the health of Spaniards. Moreover, $50 \%$ of the smokers who think the law is beneficial for health do not intend to stop smoking.

The survey found that, in general, the Spanish believe that the anti-tobacco law of 2005 is "good or very good" (71.3\%), $21.6 \%$ state that it is "bad or very bad", and $7.1 \%$ think that it is "neither good nor bad" (Table I). However, $34.7 \%$ of smokers consider the law to be negative; 13 percentage points above the average and a 17-point difference over non-smokers. In spite of these figures, 
Figure 1. Tobacco consumption in Spain by sex

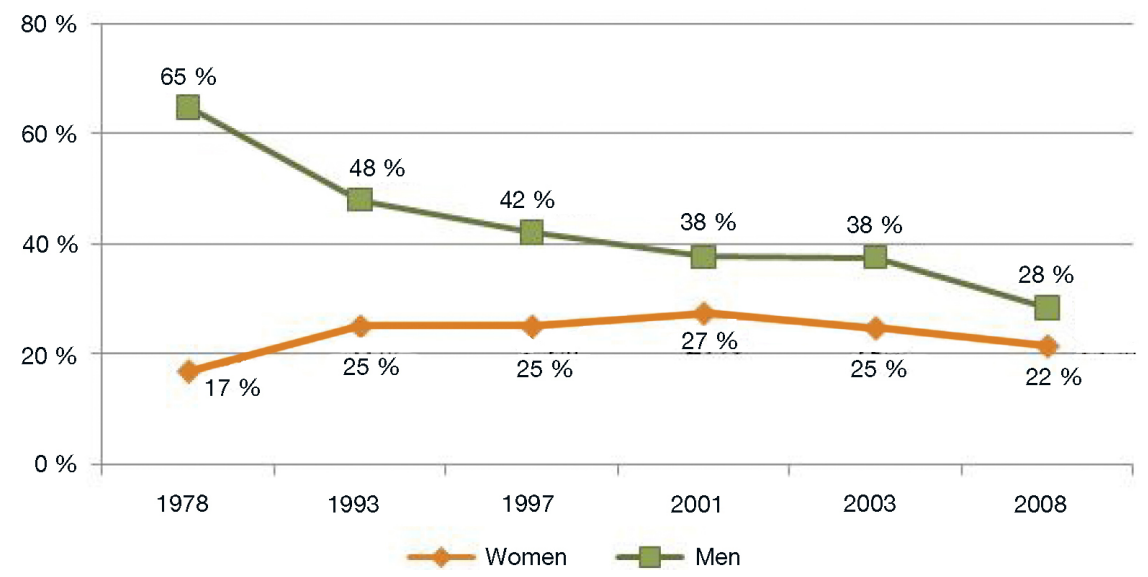

Source: The author based on data from CIS study No. 2751 on tobacco-related habits (2008). National Health Survey (data from 1978 to 2003).

Table I. Descriptive statistics for smokers, ex-smokers and non-smokers. Pearson chi-square significance test.

\begin{tabular}{|c|c|c|c|c|c|}
\hline $\begin{array}{l}\% \text { of respondents who agree with } \\
\text { the following statements }\end{array}$ & Total & Smokers & Ex-smokers & Non-smokers & Sig \\
\hline The hazards of smoking are overstated & $39.2 \%$ & $47.6 \%$ & $40.5 \%$ & $34.7 \%$ & .000 \\
\hline $\begin{array}{l}\text { Smoking is hazardous for your health } \\
\text { and measures should be taken to } \\
\text { reduce tobacco consumption }\end{array}$ & $90.8 \%$ & $84.8 \%$ & $91.3 \%$ & $93.4 \%$ & .000 \\
\hline $\begin{array}{l}\text { Smoking is a right and measures } \\
\text { should not be taken to restrict } \\
\text { tobacco consumption }\end{array}$ & $56.3 \%$ & $74.6 \%$ & $59.7 \%$ & $56.5 \%$ & .000 \\
\hline Perception of the anti-tobacco law & & & & & .000 \\
\hline Very good /Good & $71.3 \%$ & $57.9 \%$ & $77.5 \%$ & $75.3 \%$ & \\
\hline Neither good nor bad & $7.19 \%$ & $7.3 \%$ & $5.9 \%$ & $7.5 \%$ & \\
\hline Bad /Very bad & $21.6 \%$ & $34.7 \%$ & $16.5 \%$ & $17.5 \%$ & \\
\hline Effect of the law & & & & & .000 \\
\hline $\begin{array}{l}\text { The law contributes to improving } \\
\text { the health of Spanish citizens }\end{array}$ & $73.5 \%$ & $64.3 \%$ & $78.2 \%$ & $75.9 \%$ & \\
\hline $\begin{array}{l}\text { The law does not have a significant } \\
\text { effect on the health of Spanish citizens }\end{array}$ & $26.5 \%$ & $35.7 \%$ & $21.8 \%$ & $24.1 \%$ & \\
\hline
\end{tabular}

Source: The author based on data from CIS study No. 2751 on tobacco-related habits.

more than half of smokers have a positive opinion about the law (57.9\%). These percentages are somewhat lower than those found in similar studies carried out in Europe. A survey conducted in Italy, for example, found that $86 \%$ of the population supported a law to ban smoking in the workplace (Rodríguez et al., 2006).

Moreover, $73.5 \%$ of respondents believe that the law contributes to improving health. Although this figure drops by 9 percentage points among smokers, 
many of the respondents, including those who smoke, state that the law is beneficial to citizens' health. Ex-smokers were most aware of the positive effects of the law, with $78 \%$ stating that the law improves health.

The results of the multivariate analysis are shown in Table II. The resulting model is capable of classifying $75.2 \%$ of the data, although it classifies respondents who support the law more accurately than the other respondents. The sensitivity of the model is above $83 \%$.

The variables that predict attitudes towards the anti-tobacco law are shown in reverse order to that of the model input. Sociodemographic characteristics which we initially thought might be related to opinions for and against the law such as age, sex and educational level were not found to be statistically significant and have therefore been omitted from the final model. Of all the characteristics studied, vote preference in the last general elections was found to be the most significant. Respondents who voted for the conservative PP party in the last general elections were 55\% less likely to support the law than those who voted for the progressive PSOE party (reference category). Those who voted for other parties or did not vote in the last elections were also less likely to support the law.

Moreover, being a non-smoker or being bothered by smokers increases the probability of supporting the law. Those who have never smoked are 1.66 times more likely to support the law than smokers or ex-smokers, regardless of their opinions or perceptions in the other variables.

The perceived effectiveness of the law was found to have the greatest predictive power on support for anti-tobacco legislation. This factor was measured by means of three variables. The first variable refers to whether or not respondents believe that the law contributes to improving the health of Spanish citizens. Approximately four times more respondents who state that the law improves health support the law than those who believe that it is not effective, with all other variables remaining constant (e.g. smokers or non-smokers). The second variable measures the perceived effectiveness of the law in terms of reducing number of smokers. Of the respondents who believe that the restrictions on tobacco consumption have reduced number of smokers, $49 \%$ more support the law than those who believe that the law has not achieved this aim. Finally, the effect of the law on reducing number of cigarettes consumed was also found to predict support. The estimated coefficients show that the odds ratio of supporting the law is 0.549 (odds ratio $=0.549,95 \%$ CI: $0.427,0.704)$ among those who think that smokers have not changed their smoking habits compared to those who believe that tobacco consumption has decreased. This means that the likelihood of supporting the law is almost twice as high among respondents who believe that the law will encourage people to smoke less than among those who believe that the law will not change people's smoking habits, controlling for the rest of the variables. Moreover, there is a three-fold increase in the odds of supporting the law when comparing these respondents to those who state that smokers will smoke more after the passage of the law. 


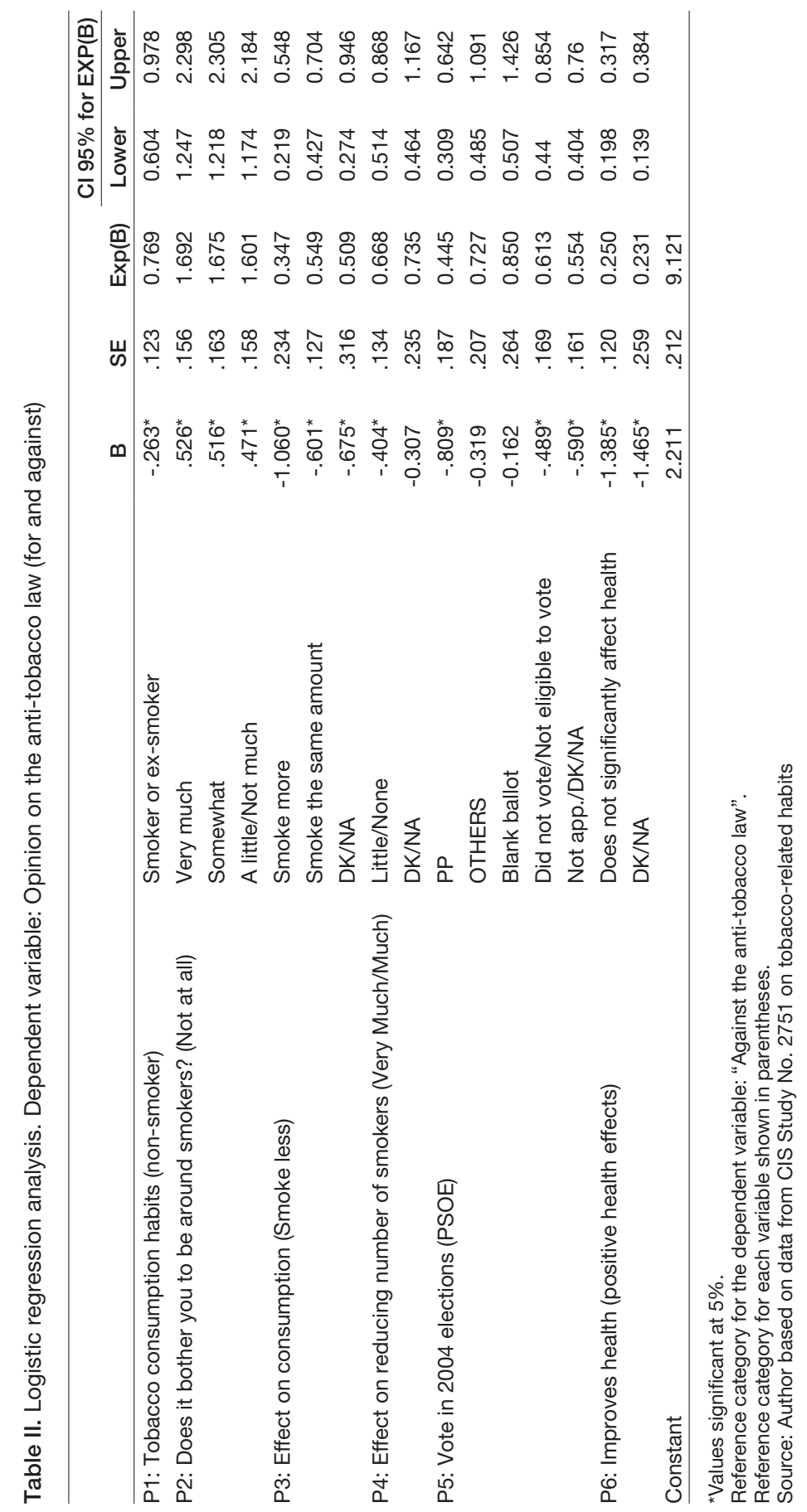


To summarize, the profile of citizens who support the anti-tobacco law (those with a 0.94 probability of being in favor of the law) corresponds to an individual who does not smoke, is bothered by smokers, believes that the law is effective in reducing both number of smokers and number of cigarettes consumed, has voted for the PSOE party and states that the law has improved citizens' health. Citizens who are against the anti-tobacco law (those with a 0.04 probability of being in favor of the law) include those who smoke or who have smoked, are not bothered by other smokers, do not believe that the law has been effective in reducing consumption, have voted for the PP party and state that the law does not have a significant influence on the health of Spanish citizens.

\section{Discussion}

The anti-tobacco law that came into force in Spain in late 2005 was permissive and partial. According to reports by the $\mathrm{WHO}$, total bans on tobacco consumption are better and more effective than partial restrictions (Mackay and Eriksen, 2002) as such restrictions lead citizens to seek alternatives to tobacco consumption. To address this issue, the government reformed the law to align it more closely with international guidelines, making it even more restrictive than the legislation being implemented in other countries of Europe (BOE, 2010; Eadie et al., 2010; Rodríguez et al., 2006: 138).

Education targeted at controlling the tobacco epidemic and gaining citizen support for anti-tobacco policies are essential in creating a favorable climate and promoting zero tolerance towards tobacco. Consensus among political parties is also important so that citizens do not confuse a major public health problem with the political ideology of a given party. When the law was passed in 2005, not a single political party in Spain openly supported the consumption of tobacco nor did politicians negate the adverse effects of tobacco in their public discourse. In fact, the law was passed thanks to the unanimous support of all the parties in parliament. In this paper, however, we have shown that citizens who voted for the PSOE party (the party that headed the efforts to enact anti-tobacco legislation) view the law in a more positive manner than those who voted for the PP party. This may help us to understand the ambiguous discourse that the PP party currently sustains on the 2010 anti-tobacco law and the possibility of reinstating the law of 2005 (El País, 2011b).

Although there is less support for anti-smoking legislation in Spain than in other countries of Europe (Rodríguez et al., 2006; Thrasher et al., 2010: 787), our study has shown that support for the 2005 law was widespread. We have also shown that one of the main factors explaining support for anti-smoking legislation is the belief that it is effective, that is, the fact that the law benefits citizens' health. This result is of great interest as it indicates that the perceived effectiveness of the law (i.e. the "goodness" of the legislation in health terms) is essential to gaining citizens' support for the newly reformed law; an aspect that both legislators and government leaders in Spain must take into account. 
Although citizens are aware that smoking is dangerous for their health and acknowledge that restrictive tobacco policies have a positive effect on health in general, they do not change their habits and continue to smoke. In short, as we stated in the introduction, citizens know that "smoking kills" and that anti-smoking legislation can contribute to improving their health, but they do not modify their behavior. In part, this conduct can be explained by Festinger's theory of cognitive dissonance (Festinger, 1957). According to Festinger, there is a tendency for people to be biased towards confirmatory information, that is, information which is consistent with their beliefs and actions and to ignore and/or reduce information that is inconsistent with their behavior (Tavris and Aronson, 2007). While this theory explains why it is difficult to change the behavior and habits of people who continue to smoke in spite of being fully aware that smoking is bad for their health and those around them, it does not mean that it is impossible to change such conduct. Although people know that smoking is harmful to their health, it is also true that they do not always look for the "ideal solution" to this dissonance, that is, to stop smoking, due partly to what Elster calls "akrasia" or weakness of the will (Elster, 1995, 2002).

In any case, according to a recent survey conducted by the Spanish Society of Family and Community Medicine (SEMFYC), 82\% of Spaniards agrees with the current anti-tobacco regulation. Among smokers, one in every three supports this regulation and would be against repealing it (El País, 2012). In this regard, individual preferences for smoking would not outweigh collective preferences in favor of a restrictive law on tobacco consumption (Dalmau and Descalç, 1999). Indeed, citizens seem to understand that there are collective rights that are necessary to preserve over individual preferences or freedoms.

To do so, it is necessary to modify current anti-smoking strategies. Health education should not be relegated to a secondary position on public health policy agendas, but must become a cornerstone of legislative and executive action. As studies have shown (Linder-Pelz, 1982), citizens' opinions about the health care they receive are an important determinant in following physicians' advice and have a decisive influence on health. When health education is targeted specifically at tobacco consumption, it is of vital importance that citizens understand and support anti-tobacco policies, become aware of the benefits to be gained and cease justifying their behavior if they are to give up smoking. As the results of this study have shown, citizens must be informed about the effectiveness of anti-smoking legislation as the availability of such information will play a key role in determining positive or negative attitudes towards the law.

The hazards of tobacco are widely known, with scientific evidence leaving no room for doubt. For this reason, government actions to restrict consumption are not only necessary, but now demanded by citizens. Banning smoking in public places is a health measure targeted at protecting the health of both smokers (by restricting areas where smoking is allowed and thus reducing overall consumption) and non-smokers (by eliminating second-hand smoke). If citizens are made aware of these benefits, governments that implement res- 
trictive anti-tobacco policies will be successful in garnering public support for such initiatives.

\section{Acknowledgements}

The authors are grateful to the Centro de Investigaciones Sociológicas (CIS) for providing the data used in this research study. The authors would also like to thank their colleagues at the IESA/CSIC for their support and suggestions to improve the paper and the analysis.

\section{Bibliographic references}

Betancourt, Lidia and Navarro, José (2001). “Tabaquismo. Panorama general y perspectivas”. Revista Mexicana de Cardiología, 12(2), 85-93.

Blake, Kelly; Viswanath, Kasisomayajula; Blendon, Robert and Vallone, Donna (2010). "The role of reported tobacco-specific media exposure on adult attitudes towards proposed policies to limit the portrayal of smoking in movies". Tobacco Control, 19, 191-196.

Boletín Oficial Del Estado Español (2005). Ley 28/2005, 309, de 26 de diciembre, 42241-42250, Madrid: BOE (online) <http://sid.usal.es/idocs/F3/LYN8583/ 3-8583.pdf>.

Boletín Oficial Del Estado Español (2010). Ley 42/2010, de 30 de diciembre, 109188-109194, Madrid: BOE (online) <http://www.boe.es/boe/ dias/2010/12/31/pdfs/BOE-A-2010-20138.pdf >.

Camarelles, Francisco (2004). "Tendencias en el consumo de tabaco en España" Atención Primaria 34(9), 463-464.

Dalmau, Juan Carlos and DescalÇ, Asensi (1999). "La multiplicidad de esquemas preferenciales: una aplicación al concepto de necesidades tutelares”. Paper presented at the VI Encuentro de la Asociación de Economía Pública. Oviedo.

Eadie, Douglas; Macaskill; Susan; Heim, Derek and Hastings, Gerard (2010). "Responding to change: how did bar workers adapt to the smoke-free legislation in Scotland?". International Journal of Environmental Health Research, 20(1), 13-26.

ELSTER, Jon (1995). Ulises y las sirenas. Estudio sobre racionalidad e irracionalidad. $1^{a}$ reimpresión, FCE, México, p. 79.

ELSTER, Jon (2002). Alquimias de la mente. La racionalidad y las emociones. Barcelona. Paidós/ El Roure.

EL PAís (2012). "El 78\% de los españoles rechaza que se dé marcha atrás a la ley antitabaco" <http://sociedad.elpais.com/sociedad/2012/05/22/actualidad/ 1337685962_578602.html>.

El PAís (2011a). "Rajoy insinúa que cambiará la ley del tabaco para que se fume en algunos bares" <http://politica.elpais.com/politica/2011/11/09/ actualidad/1320876067_636881.html>.

EL PAís (2011b). "El PP deja claro que no habrá marcha atrás en la Ley antitabaco"<http://sociedad.elpais.com/sociedad/2011/12/28/ actualidad/1325077207_286090.html>.

FernándeZ, Esteve; Villalbi, Joan R. and Córdoba, Rodrigo (2006). "Lecciones aprendidas en el control del tabaquismo en España”. Salud Pública de México, 48 (Supl. 1), 148-154. 
Festinger, Leon (1957). A Theory of Cognitive Dissonance. Stanford: Stanford University Press.

GARCÍA, Josefa (2001). "Las Administraciones Públicas y la prevención del tabaquismo". Prevención del Tabaquismo, 3(2), 53-54.

Instituto Nacional De Salud Pública (2001). "Sugestión de la sociedad mexicana de salud pública sobre el control de la adicción a la nicotina". Salud Pública de México, 43(1), 74-78.

JAMrozIK, Konrad (2004). "Population strategies to prevent smoking". BMJ 328, 759-762.

LINDER-PELZ, Susie (1982). "Toward a theory of patient satisfaction”. Social Science and Medicine, 16(5), 577-582.

López Alan D.; Collishaw, Neil E. and Pina, Tapani (1994). "A descriptive model of the cigarette epidemic in developed countries". Tobacco Control, 3, 242-247.

Mackay, Judith and ErIKsen, Michael (2002). The Tobacco Atlas. Geneva: World Health Organization (online) <http:/www.who.int/tobacco/media/en/title.pdf>

Muggli, Monique E.; Lockhart, Nikki J.; Ebbert, Jon O.; JimeneZ-Ruiz, Carlos A.; Riesco Miranda, Juan Antonio and Hurt, Richard (2010). "Legislating tolerance: Spain's national public smoking law”. Tobacco Control, 19, 24-30.

Murray, Christopher J. and López, Alan D. (1997). "Global mortality, disability and the contribution of risk factors: Global Burden of Disease Study". Lancet 349, 1436-42.

Pierce, John P. and LEON, María E. (2008). "Effectiveness of smoke-free polices". The Lancet Oncology, 9, 614-615.

Rodríguez, Teresa; Gallus, Silvano; Chatenoud, Liliane; Zuccaro, Piergiorgio; Colombo, Paolo; Apolone, Giovanni; Pacifici, Roberta; Garattini, Silvio and LA VeCCHIA, Carlo (2006). "Efecto de la nueva regulación antitabaco en Italia”. Salud Pública de México, 48 (Supl. 1), 137-139.

TAVRIS, Carol and Aronson, Elliot (2007). Mistakes were made (but not by me): Why we justify foolish beliefs, bad decisions, and hurtful acts. Canada: Harcourt.

Thrasher, James F.; Besley, John C. and Gonzalez, Wendy (2010). "Perceived justice and popular support for public health laws: A case study around comprehensive smoke-free legislation in Mexico City". Social Science and Medicine, 70, 787-793.

US Department Of Health And Human Services (2006). The health consequences of involuntary exposure to tobacco smoke: a report of the Surgeon General, Washington: US Department of Health and Human Services.

World Health Organization (1952). Constitution of the World Health Organization. Handbook of basic documents (5 ${ }^{\text {th }}$ ed.). Geneva: Pelais des Nations 3-20.

World HEALTH ORGANIZATION (2000). WHO framework convention on tobacco control, Geneva: WHO (online) <http://apps.who.int/gb/archive/pdf_files/EB107/ ee30.pdf>.

World Health Organization (Regional Office for Europe) (1999). Tercer Plan de Actuación para una Europa sin Tabaco 1997-2001, Madrid: WHO 